\title{
Configurações
}

Revista de sociologia

\section{Ana Mafalda Leite, Hilary Owen, Rica Chaves e Livia Apa (orgs.). Nação e Narrativa Pós-Colonial I - Angola e Moçambique. Lisboa: Edições Colibri, 2012}

Raquel Ribeiro

\section{(2) OpenEdition Journals}

Edição electrónica

URL: http://journals.openedition.org/configuracoes/2186

DOI: $10.4000 /$ configuracoes. 2186

ISSN: 2182-7419

Editora

Centro de Investigação em Ciências Sociais

Edição impressa

Data de publição: 1 Dezembro 2013

Paginação: 229-231

ISBN: 1646-5075

ISSN: 1646-5075

\section{Refêrencia eletrónica}

Raquel Ribeiro, « Ana Mafalda Leite, Hilary Owen, Rica Chaves e Livia Apa (orgs.). Nação e Narrativa

Pós-Colonial I - Angola e Moçambique. Lisboa: Edições Colibri, 2012 », Configurações [Online] ,

12 | 2013, posto online no dia 08 outubro 2014, consultado o 19 abril 2019. URL : http://

journals.openedition.org/configuracoes/2186; DOI : 10.4000/configuracoes.2186

Este documento foi criado de forma automática no dia 19 Abril 2019.

(c) CICS 


\title{
Ana Mafalda Leite, Hilary Owen, Rica Chaves e Livia Apa (orgs.). Nação e Narrativa Pós-Colonial I - Angola e Moçambique. Lisboa: Edições Colibri, 2012
}

\author{
Raquel Ribeiro
}

1 Resultando de um longo projeto de investigação transnacional financiado pela FCT e onde se incluem alguns dos mais interessantes críticos dos estudos pós-coloniais lusófonos (em Portugal, no Brasil ou no Reino Unido), Nação e Narrativa Pós-Colonial I - Angola e Moçambique é o primeiro de vários volumes dedicados às literaturas africanas lusófonas, neste caso, de Angola e Moçambique.

2 A antologia apresenta ensaios por vezes em análises comparatistas (como nos da autoria de Inocência Mata, Carmen Lúcia, Tindó Secco ou Kamila Krakowska), outras vezes centrando-se somente na obra de um autor (como é o caso do angolano Ruy Duarte de Carvalho, foco do ensaio de Ana Paula Tavares ou de Rita Chaves).

3 Contudo, mais do que uma simples coletânea sobre a "ideia de nação" na ficção, poesia ou ensaio de autores angolanos ou moçambicanos do século XX, ao dividir esta obra em cinco grandes blocos - "Temas da história", "Temas da viagem", "Estratégias discursivas", "O estado das teorias” e, finalmente, “A biblioteca pós-colonial” -, as organizadoras estarão, de certa forma, a compor uma maneira crítica de ler estes textos (pós)-coloniais em língua portuguesa (e não só), já não apenas segundo temáticas abordadas nas obras em causa, mas articulando entre elas um diálogo complexo, traçando cruzamentos teóricos, críticos, por vezes até polémicos. Ao estabelecer esses cruzamentos, esta obra enriquece e atualiza, assim, a leitura de uma literatura que poderia estar hoje, quarenta anos depois das independências das antigas colónias portuguesas em África, a cair num solipsismo autorreferencial, esgotando-se, enfim, no recurso às mesmas teorias para acompanhar as 
mesmas leituras das mesmas obras dos mesmos autores, muitos deles já canónicos - como Mia Couto, Pepetela ou Luandino Vieira, a título de exemplo.

Isto não se passa, de facto, com Nação e Narrativa Pós-Colonial I, e ainda bem, porque é precisamente "ao lermos as narrativas angolana e moçambicana [que se] detectam trânsitos internos no sentido de remapeamento de centros hegemónicos e alargamento a outras zonas subalternizadas da nação", escreve Ana Mafalda Leite na Introdução.

Daí, talvez, a importância do tema da "ficção na história" ou da "história na ficção" em alguns dos ensaios aqui apresentados (como o de Alberto Oliveira Pinto), a ideia de "dever de memória" e de testemunho (como no ensaio de Sheila Khan), e, destaco sobretudo, a temática da viagem, a fuga do centro urbano e da voracidade da(s) capital(is) póscoloniais para espaços ainda pouco explorados pelos críticos (e por vezes também pelos autores), sejam eles rurais por oposição a urbanos; o grande Sul por oposição à visão luando-cêntrica na literatura angolana; o oceano Índico por oposição aos estudos do "Black Atlantic" no caso de Moçambique. Essa fuga ao centro é muito bem explorada neste volume, o que é de louvar, porque o mesmo vórtex que obrigava a uma leitura de África a partir da "metrópole" durante o período colonial parecia ter tomado agora conta dos estudos pós-coloniais, sempre a partir das suas capitais - Luanda ou Maputo -, canonizando-se vozes, olhares, contemplações, normativizando a "ideia de nação", de género, de religião ou até de sexualidade, sempre a partir de um centro (e, por isso, a partir de uma ideia de poder).

6 É esse centro que é desconstruído em Nação e Narrativa Pós-Colonial I: daí a chamada de atenção para as três últimas secções do volume, "Estratégias discursivas", "O estado da teoria" e "A biblioteca pós-colonial"; secções essas onde me parece que este volume enriquece consideravelmente a própria "biblioteca" de estudos pós-coloniais lusófonos. Isto porque articula diálogos translinguísticos, questionando teorias e metodologias de literaturas africanas francófonas ou anglófonas (como o trabalho de Elena Brugioni); reavaliando o legado dos estudos do Subalterno (como no caso do ensaio de Manuela Ribeiro Sanches); colocando-os sempre em confronto com a ideia de uma Europa pós-colonial e pós-imperial (vide ensaio de Paulo de Medeiros); subvertendo a legitimidade do "uso da língua" em relação ao género do autor (como aponta Hilary Owen, comparando Mia Couto e Paulina Chiziane); isto sempre dentro do contexto do problemático conceito de "Lusofonia" (vide Jessica Falconi); contemplando de forma assertiva a questão do género literário, já não imaginando a narrativa da nação somente no romance ou na poesia, mas recorrendo também ao ensaio, à oralidade, à fotografia ou ao cinema para contar "história(s)" (como nos ensaios de Livia Apa e Ana Paula Tavares).

7 Para além da secção "Biblioteca pós-colonial", que, de certa maneira, vai ao encontro dos ensaios apresentados e, até certo ponto, confere a este excelente volume um pendor didático e de grande utilidade para investigadores na área, destaco, por fim, o ensaio de Maria Paula Meneses, "Nação e narrativas pós-coloniais: interrogações em torno dos processos identitários em Moçambique", que me parece abrir a porta a reflexões futuras no campo dos estudos pós-coloniais, em geral, e não só nos lusófonos. Em primeiro lugar porque, como já víramos em ensaios deste volume, o cruzamento de géneros - literatura, poesia, antropologia, história, ficção, testemunho - poderá, de certa maneira, enriquecer a leitura dessa "ideia de nação" ao problematizar, em campos epistemológicos complexos, onde se requerem outras metodologias de análise que não as dos estudos literários per se, questões como delimitação de fronteiras (físicas, de género, linguísticas, de raça, urbanas vs. rurais, centros e periferias, Norte e Sul), isto é, formas como o poder se exerce - e que 
discurso e que história desse poder se contam. Ao convocar a identidade nacional (neste caso, de Moçambique) como um "projecto em construção", questionando, por exemplo, o recurso a teorias do "Black Atlantic" para analisar dinâmicas culturais em Moçambique e a tendência da crítica em "inventar um universo homogéneo" do pós-colonialismo lusófono, quando essa homogeneidade de facto não existe, Meneses interroga o conceito de "descolonização" como um processo em curso, de longue durée, e não simplesmente de rutura, que não pode ser sempre reduzido aos prefixos pré- e pós-, mas que deve ser lido como uma "disputa permanente sobre as representações e políticas nas ex-colónias e nas ex-metrópoles, num complexo jogo de espelhos".

\section{AUTHOR}

\section{RAQUEL RIBEIRO}

University of Nottingham

raq.ribeiro@gmail.com 